\title{
بعض الآثار السلبية لتطبيق مجانية التعليم الأساسي في محافظة سوهاج
}

\author{
أ.د// مصطقى محمد رجب \\ أستاذ أصول التريية المتفرغ - كلية التربية جامعة سوهاج

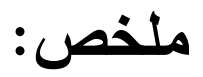

بالرغم من وجود عديد من الآثار الإيجابية لمجانية التعليم بمصر ؛ في تحقيق تكافؤ الفرص

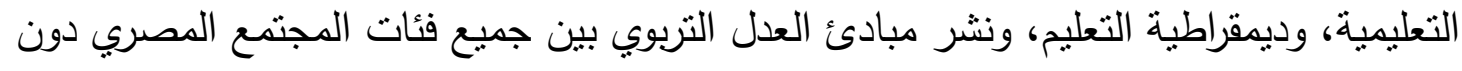

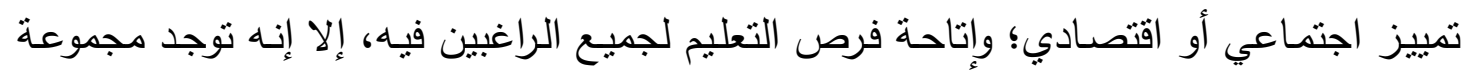

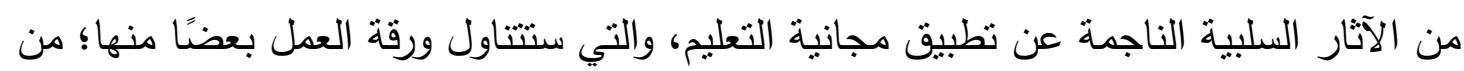

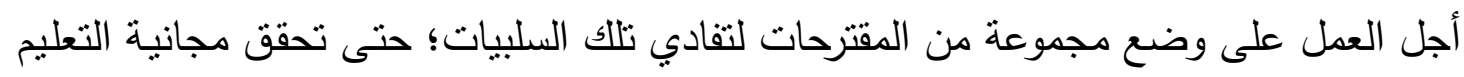

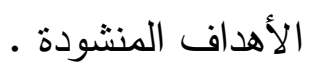

يجب أن يكون التعليم حقًا مكفولا لجميع المواطنين، وخاصة بمحافظة سوهاج التي تعد من النا

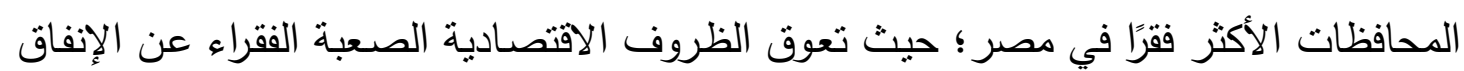

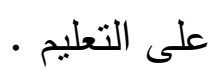

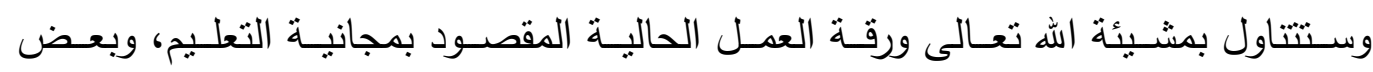

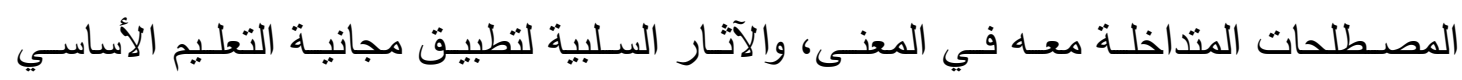

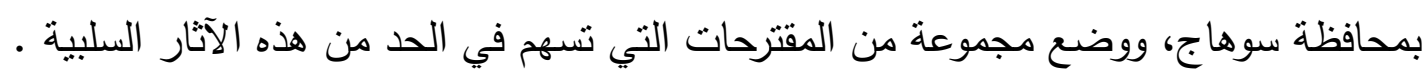

\section{مقدمة:}

يعد التعليم الركيزة الأساسية للنهوض بالمجتمع المصري من عثراته، فالتعليم هو أساس

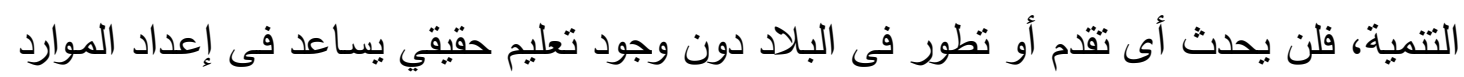

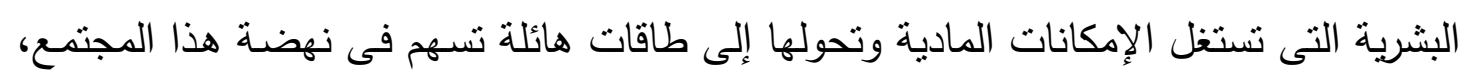

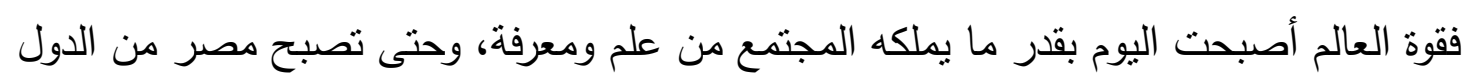

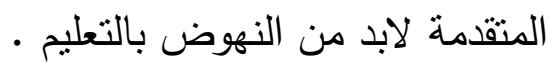

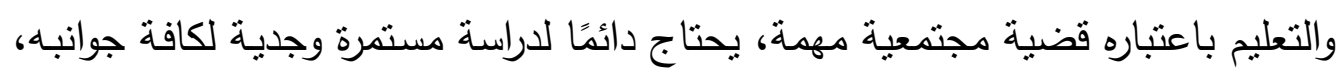

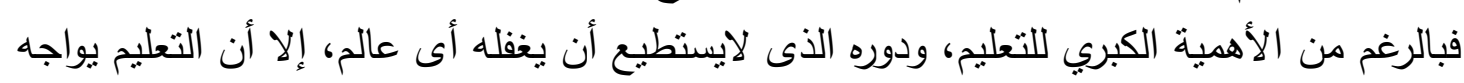


فى الآونة الأخيرة عديدًا من القضايا التى تمثل عائقًا فى وجه التعليم والمجتمع، فأصبح عاجزًا

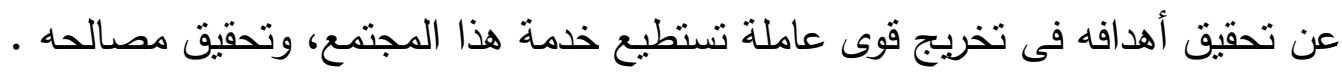
فالتعليم يواجه عدة قضايا، تعكس بظلالها سلبيًا على العملية التربوية وعناصرها المختلفة

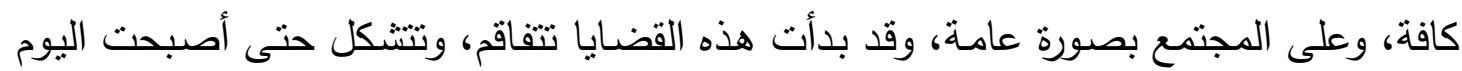

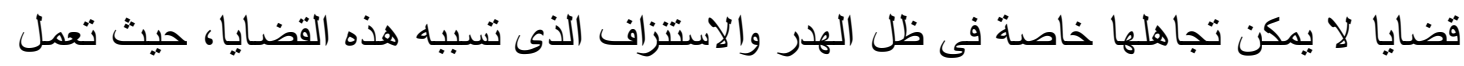

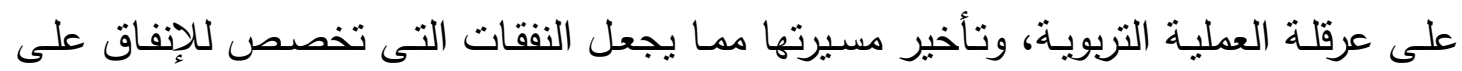

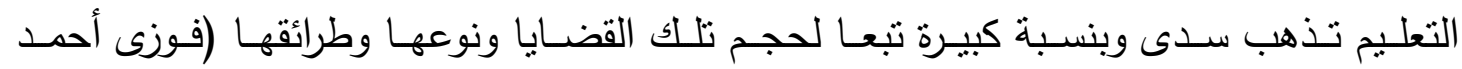

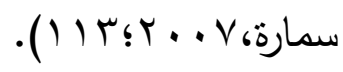

ومن أبرز تلاك القضايا قضية مجانية التعليم والآثار السلبية الناتجة عن تطبيقها في ظل التل

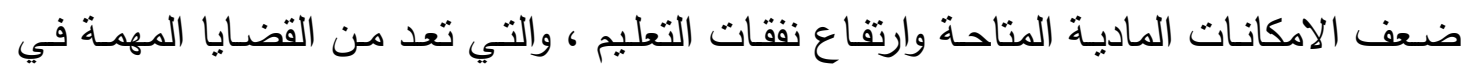

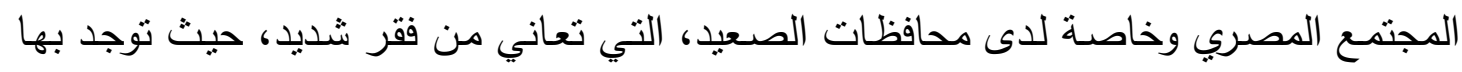

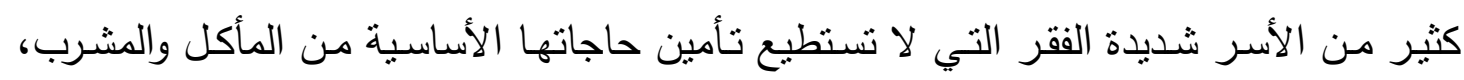

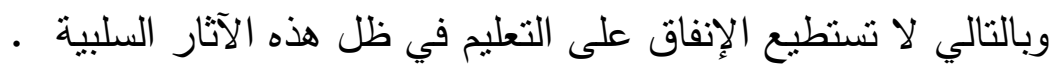

وتعد تلك القضية من القضايا المهية لأنها تركز على التعليم الذي يعد حق لكل مواطن

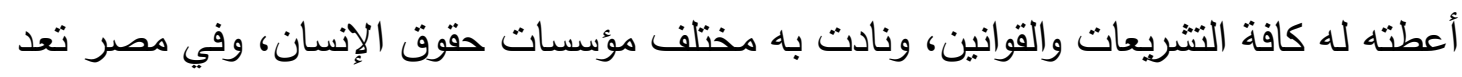

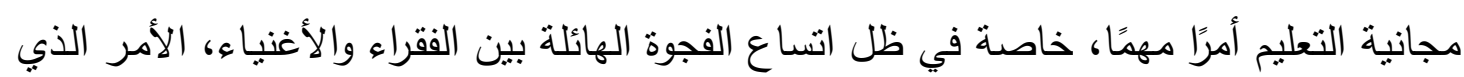

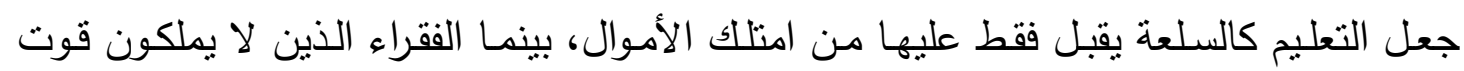

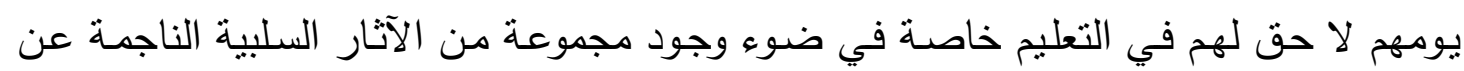

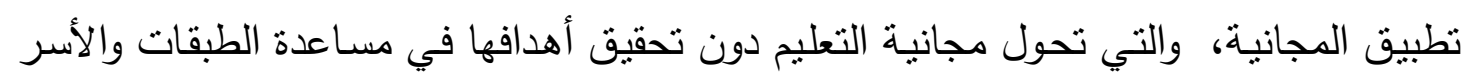

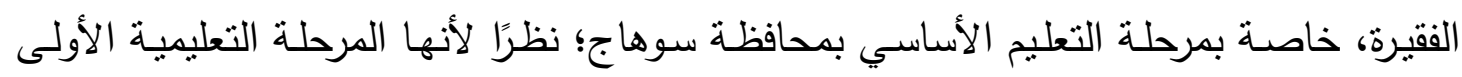

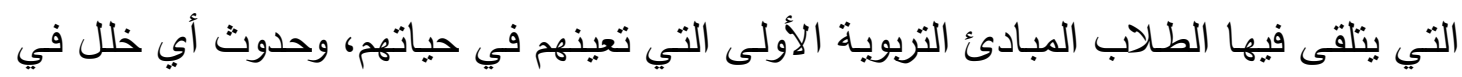

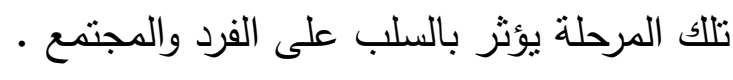

\section{أولًا: المقصود بمجانية التعليم:}

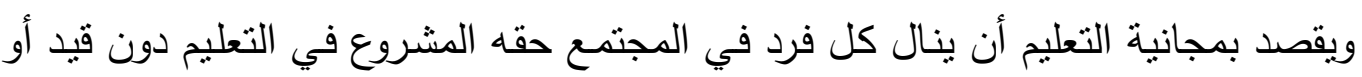

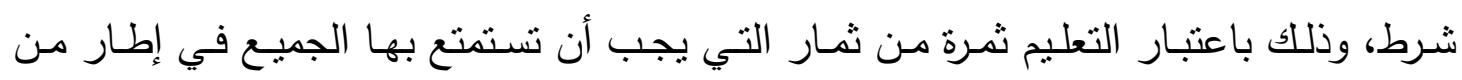

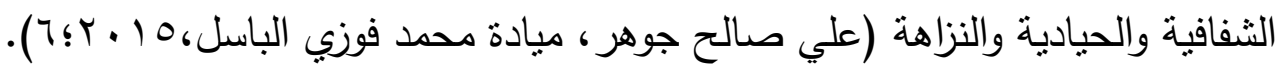

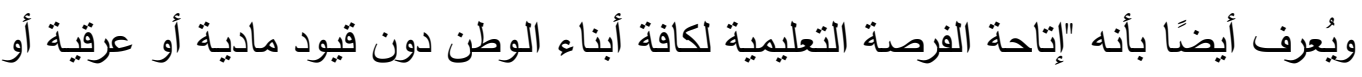

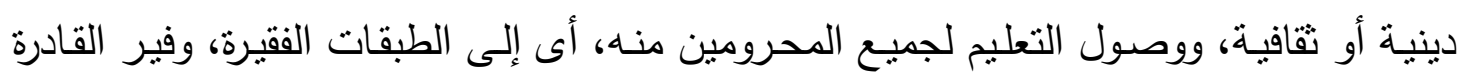

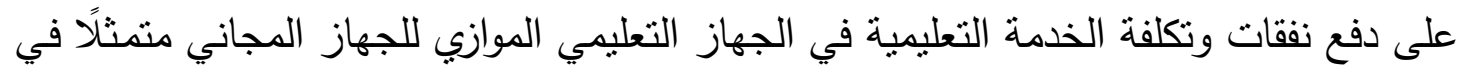

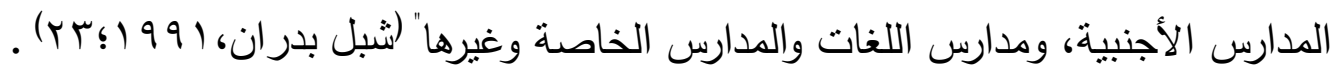




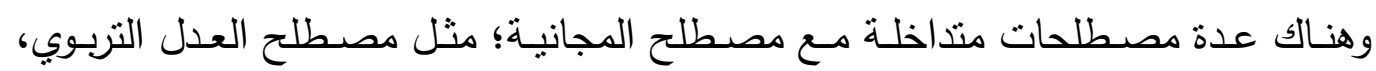
وتكافؤ الفرص التعليمية، وديمقراطية التعليم، وستوضحهم الدراسة في النقاط التالية:

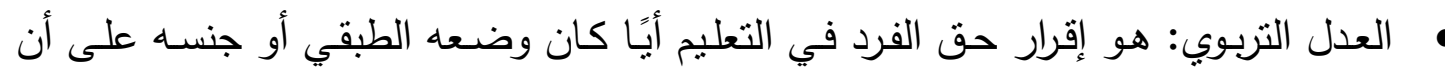
تتوفر الخدمات التعليمية بحيث تكون مجانية ومستمرة، وتقابل التباين بين الأفراد والبيئات،

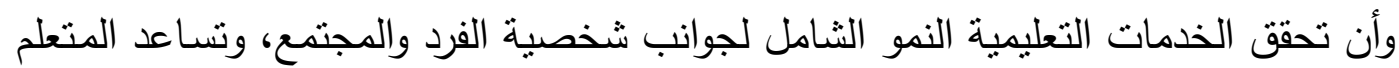

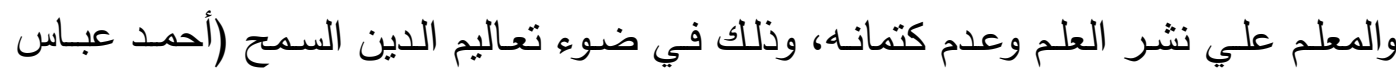

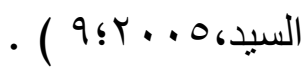

تكافؤ الفرص التعليمية: نوفير فرص تعليمية متكافئة لتتمية قدرات واستعدادات ومواهب كل

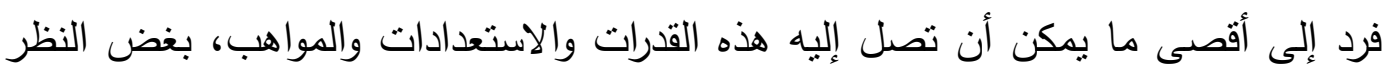
عن الأحوال المادية للفرد أو المستوي الاجتماعي والاقتصادي له له لهابل (حسن سلامة

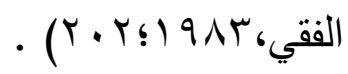

ديمقراطية التعليم: إعطاء كل مواطن حقه في التعليم بغض النظر عن قيود الجنس والنوع

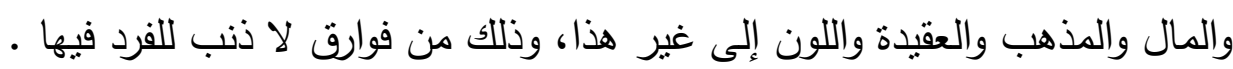
وتوجد عدة عوامل أثرت على مجانية التعليم ويمكن إجمال تلك الأسباب في (علي صالح

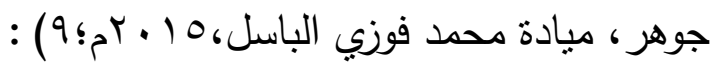

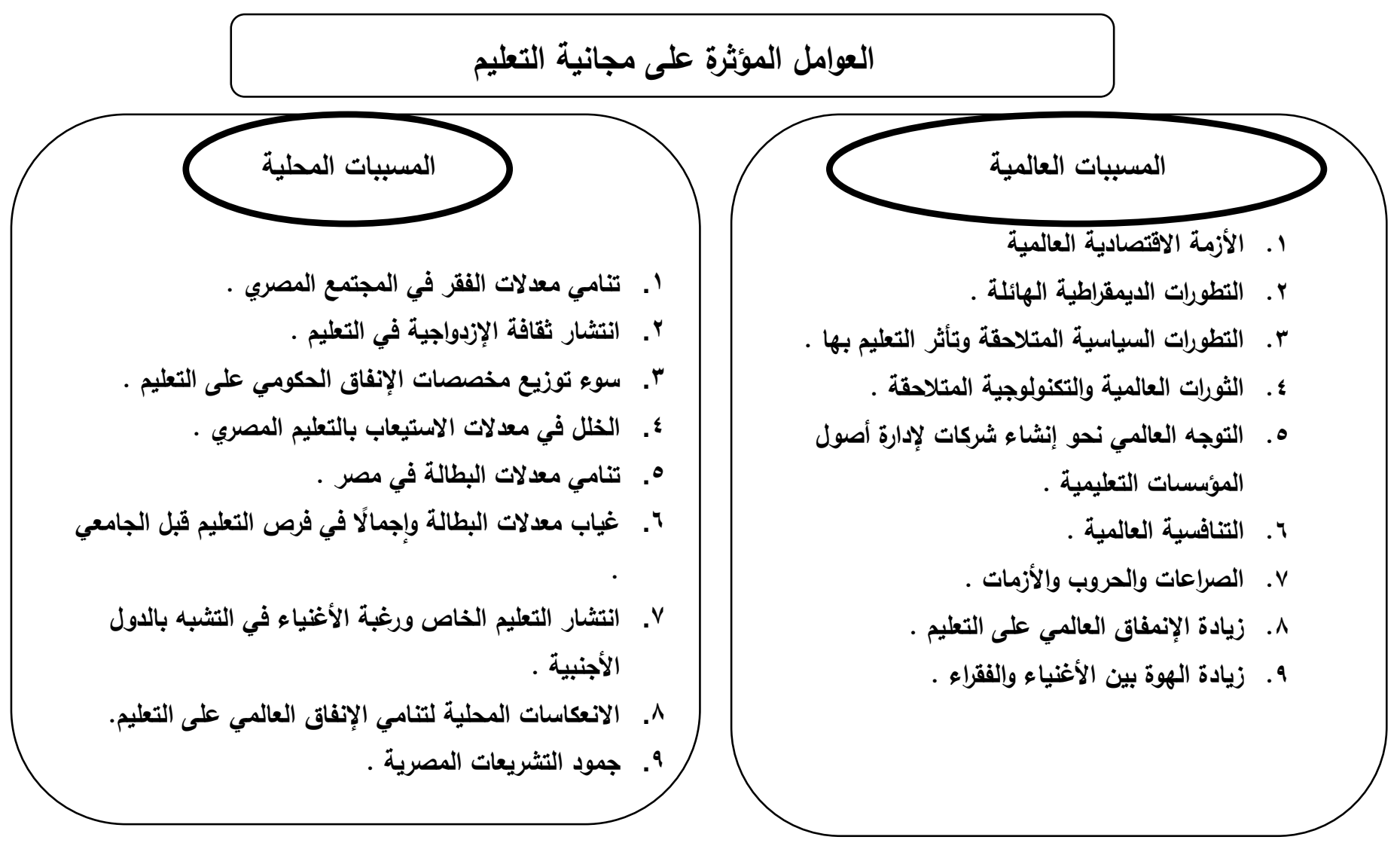




\section{الآثار العلبية لتطبيق مجانية التعليم الأساسي بمحافظة سوهاج:}

يجب أن يكون التعليم حقًا مكفولا لجميع المواطنين، وخاصة بمحافظة سوهاج التي تعد من

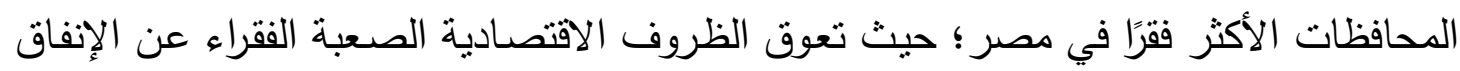

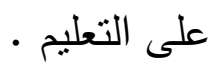

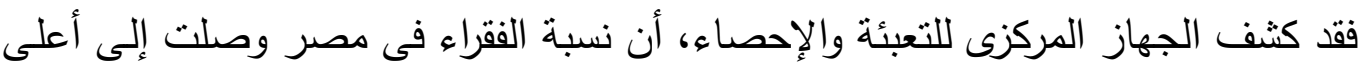

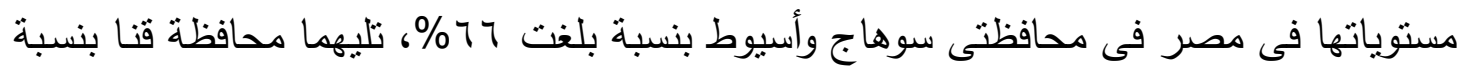
. \%०र

وبالرغم من وجود عديد من الآتار الإيجابية لمجانية التعليم بمصر ؛ في تحقيق تكافؤ

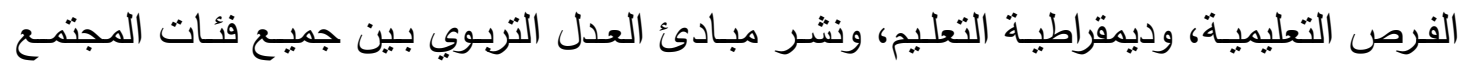

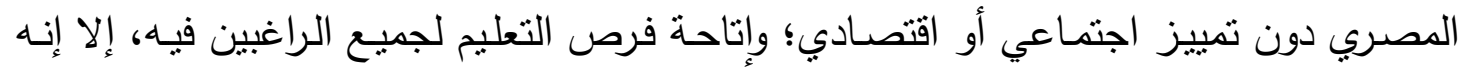

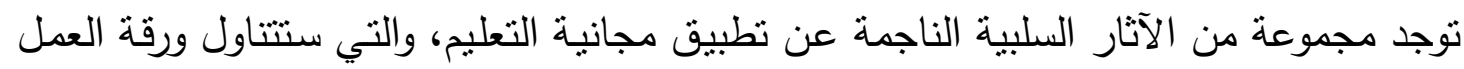

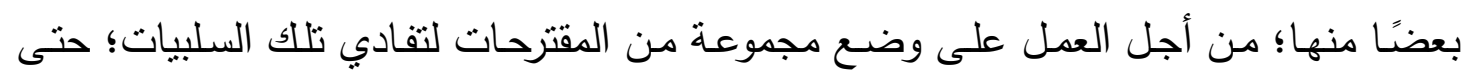

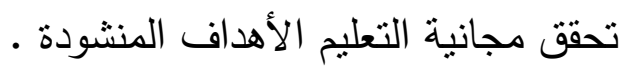

ومـن أبـرز تلـك الآثـار السـلبية لتطبيـق مجانيـة التعلـيم الأساسـي بمحافظـة سـوهاج؛ وستوضحهم الدراسة من خلال النقاط النالية:

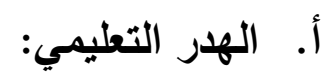

من الآثار السلبية لتطبيق مجانية التعليم الأساسي بمحافظة سوهاج الهدر التعليمي، والذي

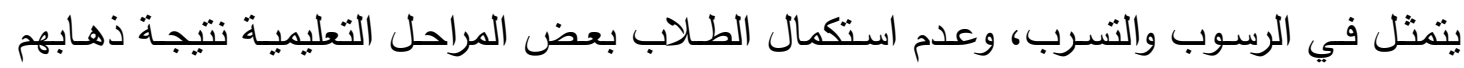

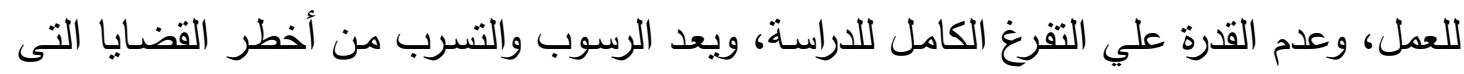

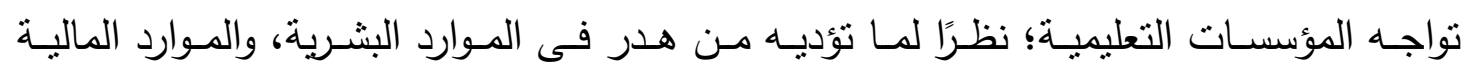

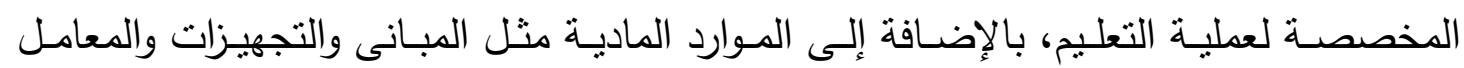

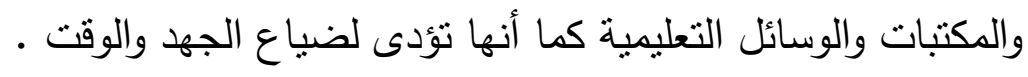

وتعد ظاهرة التسرب الدراسي والرسوب صورة من صور الهدر التربوي والتى لها كثير من التهن

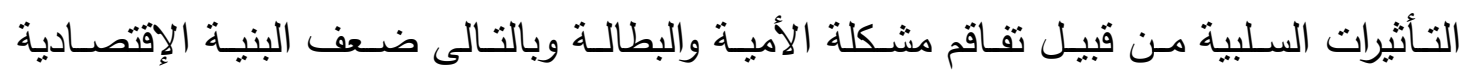

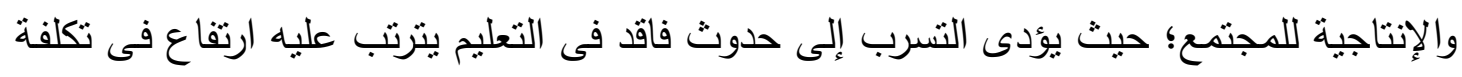

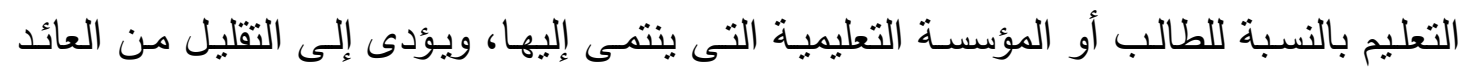

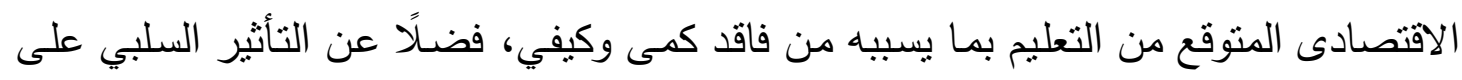

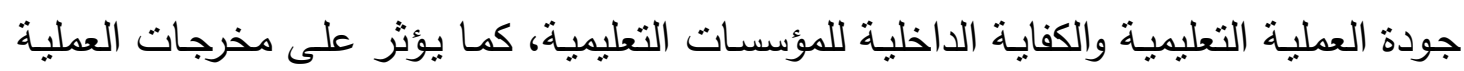

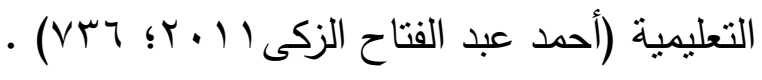


ويتسرب من التعليم آلاف من التلاميذ الذين يكملون المرحلة الابتدائية، فينقطعون تمامًا

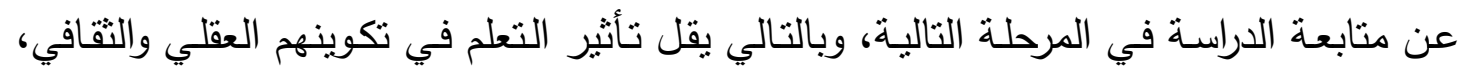

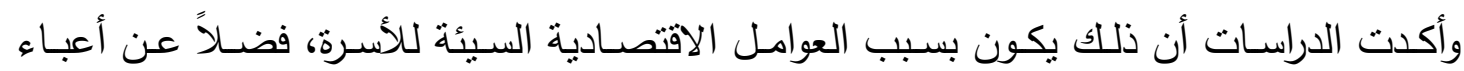
الدروس الخصوصية التي تمثل أخطر مفسدة وأبشعها في مسيرة التعليم المصري (إسماعيل

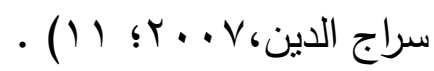

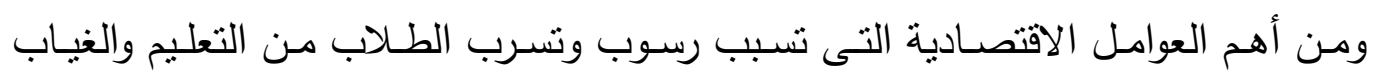

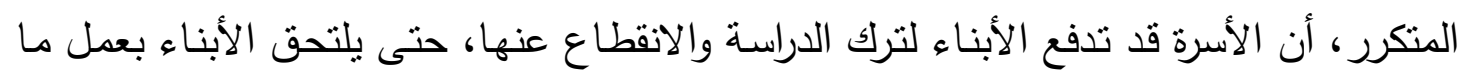

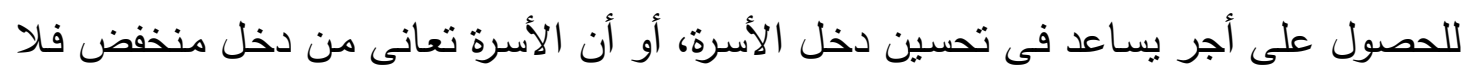

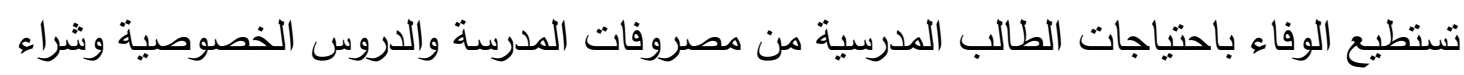

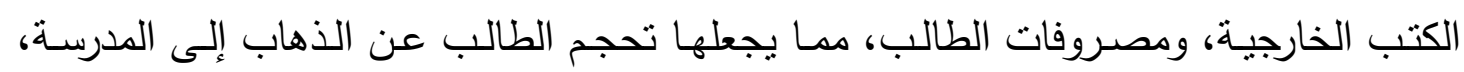

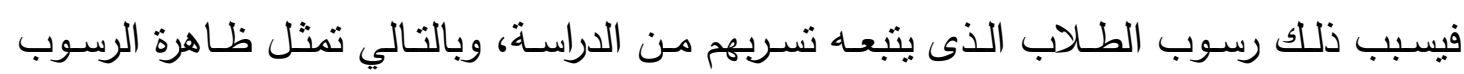

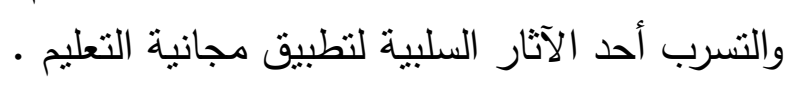

\section{ب. زيادة الأعباء على الدولة :}

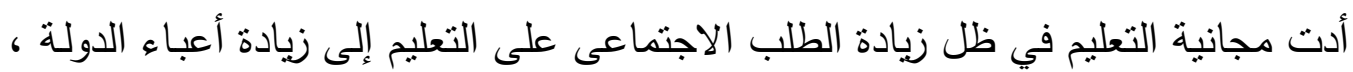

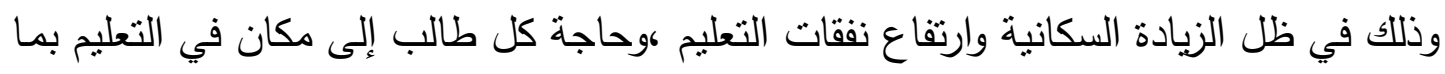

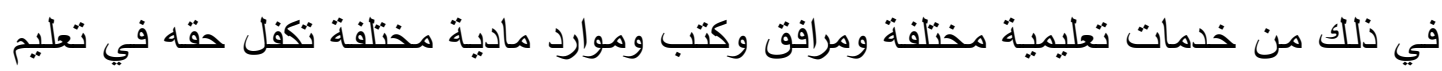

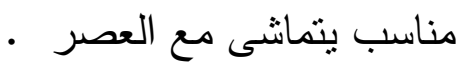

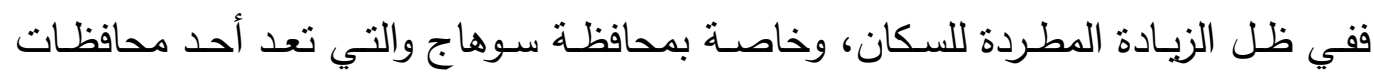

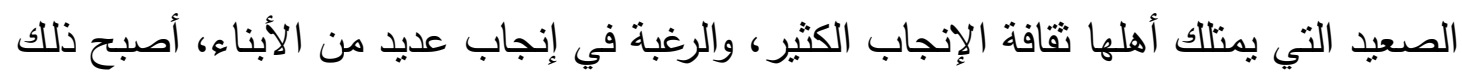

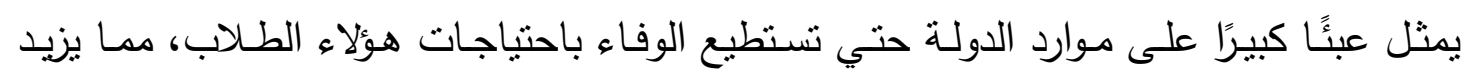

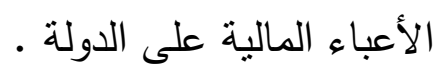

\section{ج. الكثافة الطلابية وضعف القدرة الاستيعابية للمؤسسات التعليمية الحكومية :}

تعانى المدارس المصرية من ارتفاع الكثافة الفصلية وخاصة في المحافظات الفقيرة ومنها

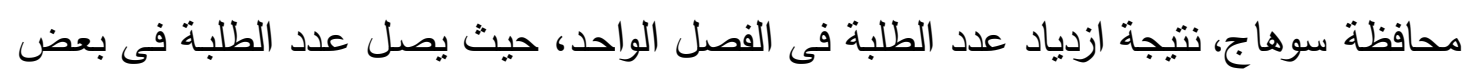

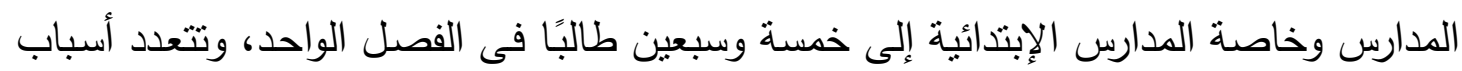

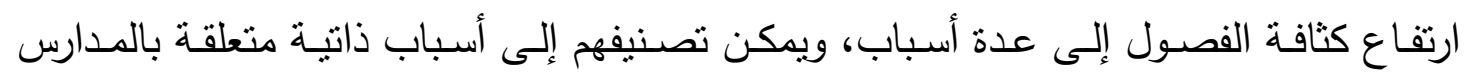

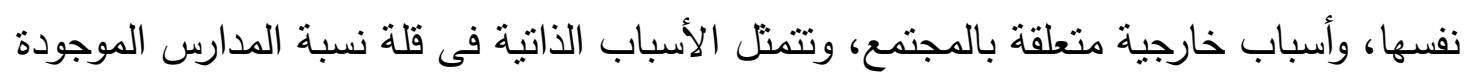

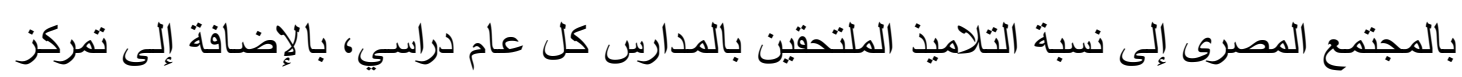

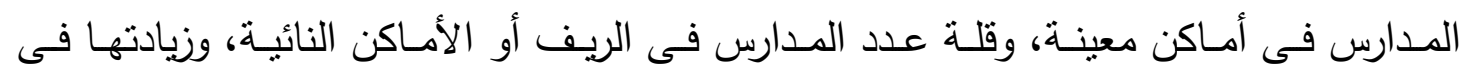


الحضـر ، أمـا الأسباب الخارجيـة فتتمثل فى زيـادة الطلب الاجتمـاعى على التعليم؛ والزيـادة

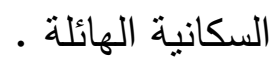

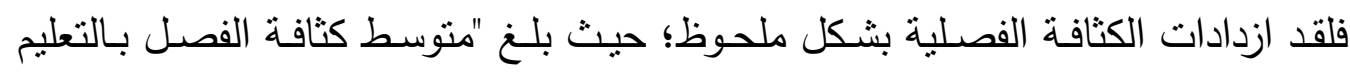

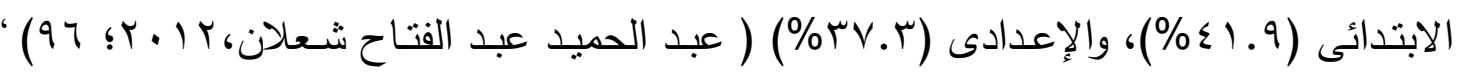

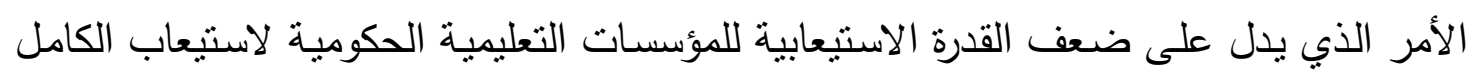

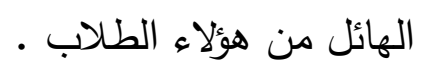

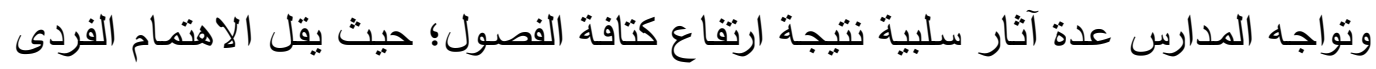

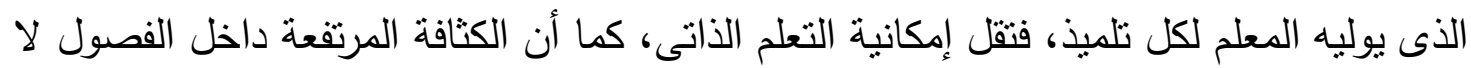

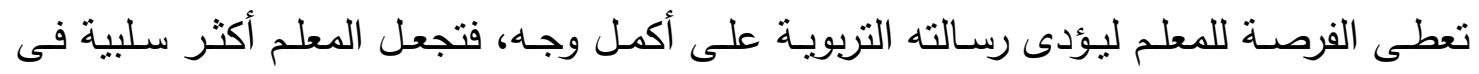

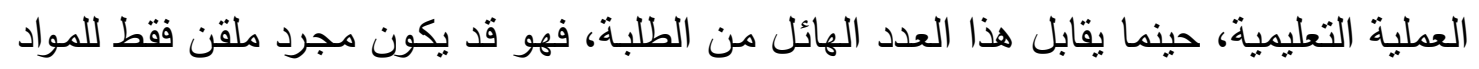

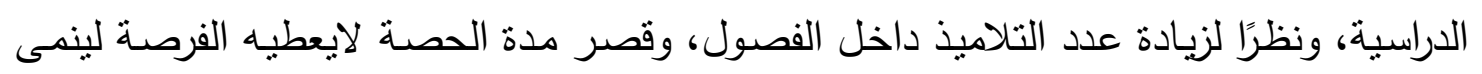

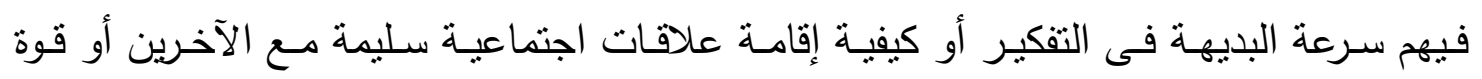

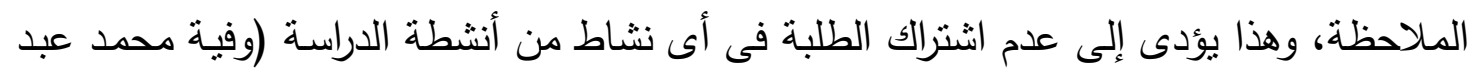

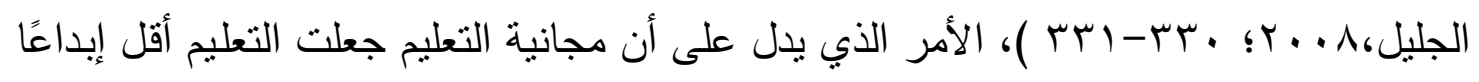

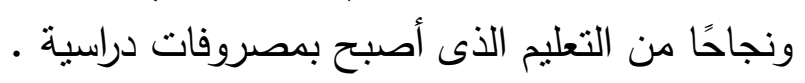

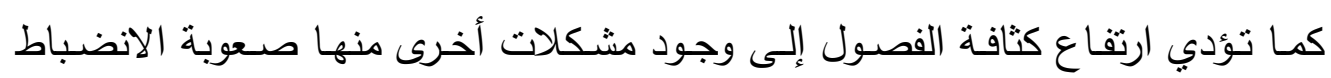

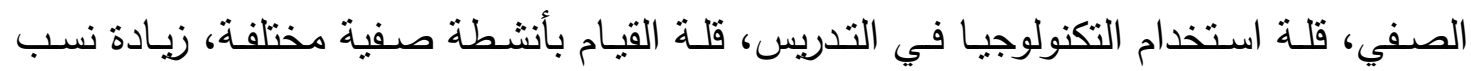

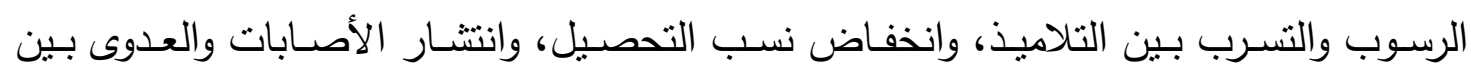

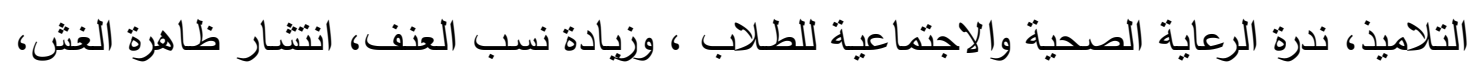

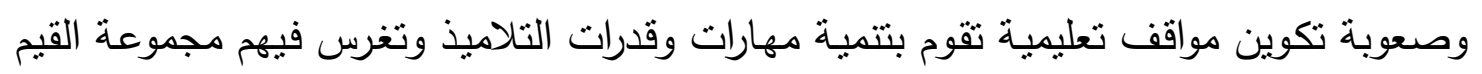

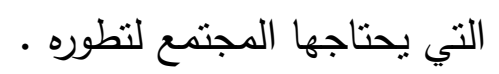

\section{د. ضعف مستوى الخريجين وتدهور سوق العمل:}

من الآثار السلبية لتطبيق مجانية التعليم ضعف مستوى الخريجين، و ذلك نتيجة الأعداد

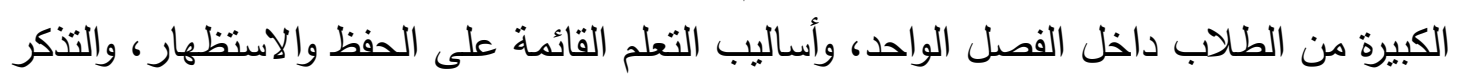

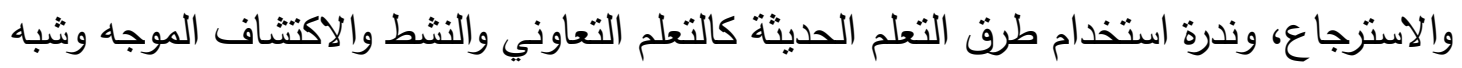

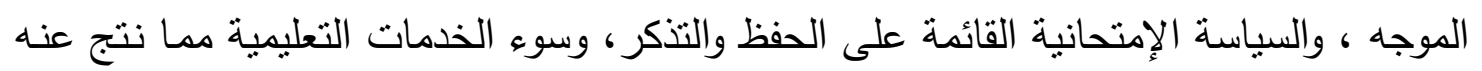

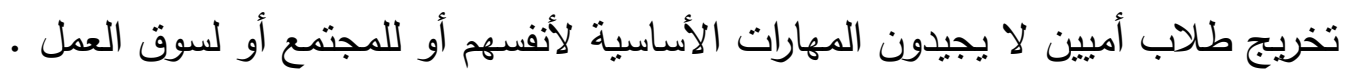

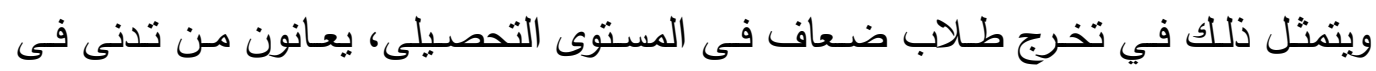

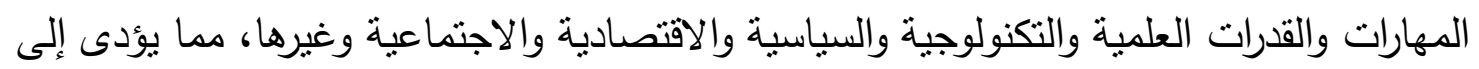

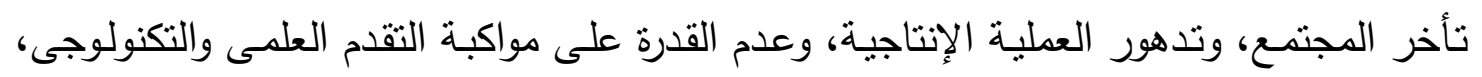




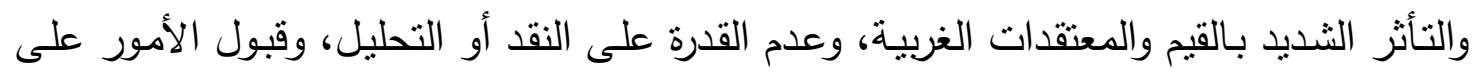

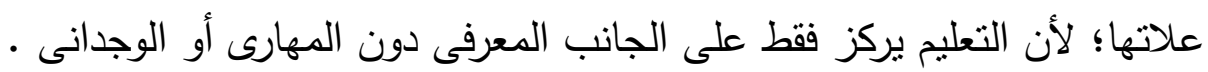

هـ تلني جودة الخدمات التعليمية:

تعتبر محافظة سوهاج من أكثر المحافظات فقرا فى الخدمات العامة التي تقدم لأفراد

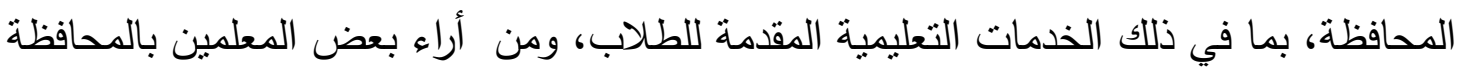

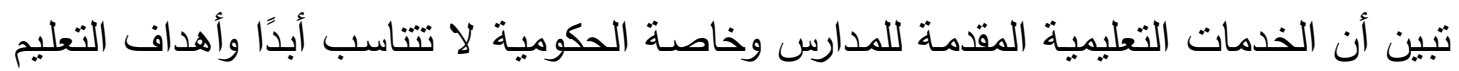
الموضوعة، وضعف هذه الخدمات واضح تماما لجميع المسئولين ويؤثر سلبا على مستوى المتعلم فيوجد ضـف واضـح في الإمكانات التعليمية المتوفرة بالمدارس بالمحافظة، من المقاعد

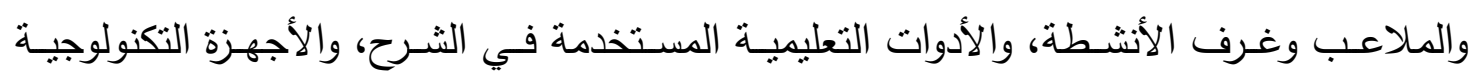
الحديثة، مما أدي إلى تدهور العملية التعليمية .

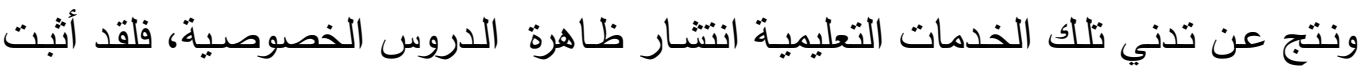

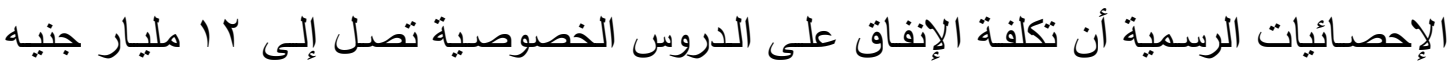

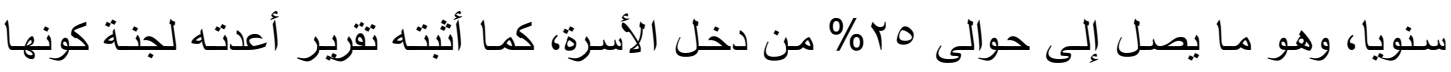

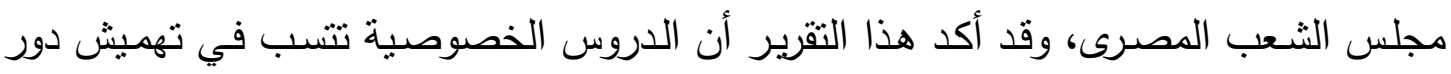

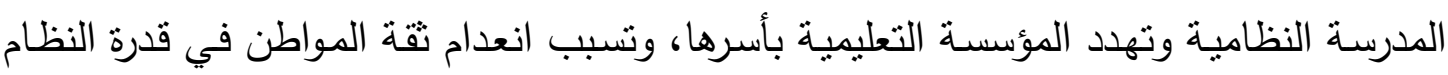

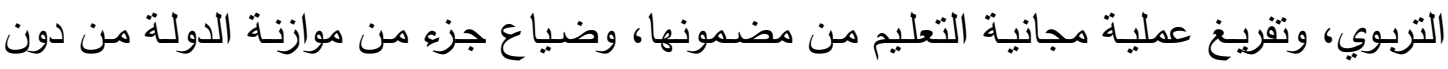

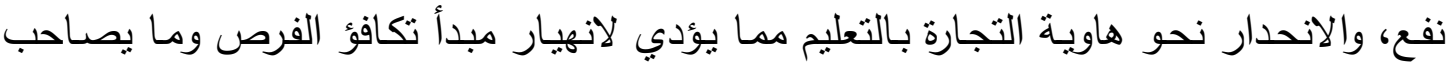

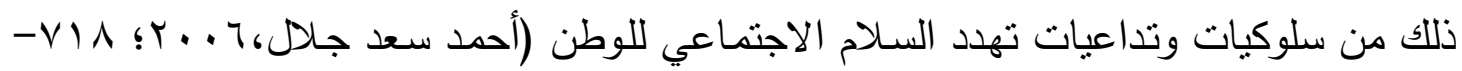

والدروس الخصوصبة على انتشـارها إلا أنها تكلف الأسرة مبالغ طائلة، تذهب هدرًا في

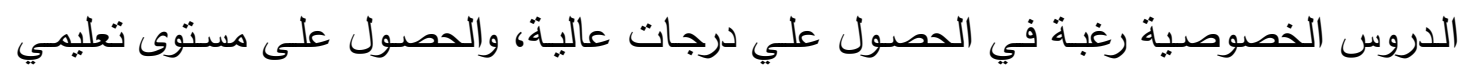

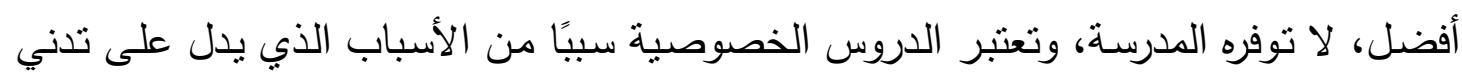

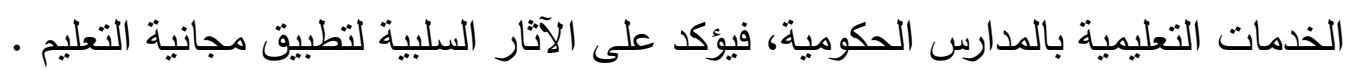

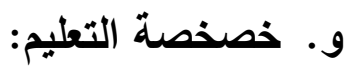

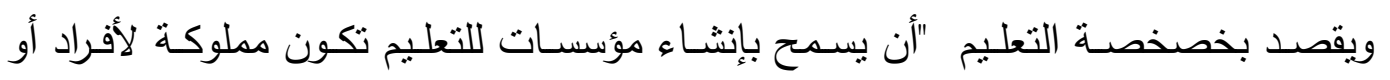

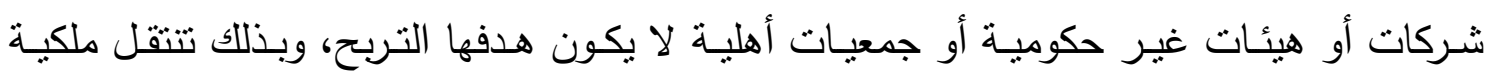

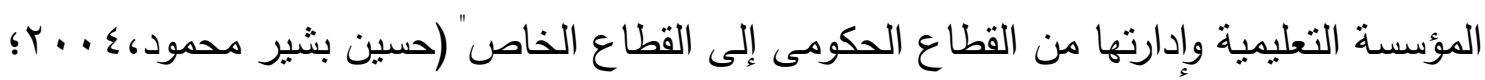

ويعد التوجه نحو الخصخصة من الآثار السلبية لتطبيق مجانية التعليم وخاصة في مرحلة

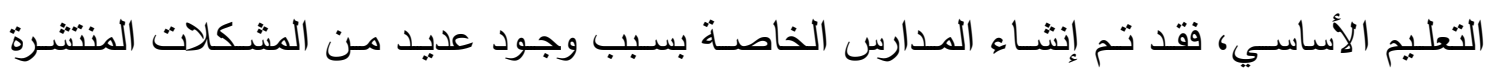
بمختلف مراحل التعليم المجاني . 
ومن أهم الأسباب والمبررات التى دعت إلى ظهور خصخصة التعليم:

ا. الزيـادة فى أعداد الطـلاب، والتـى تفوق الكثافة الاستيعابية للمدارس والجامعـات الحكوميـة

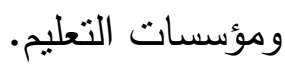

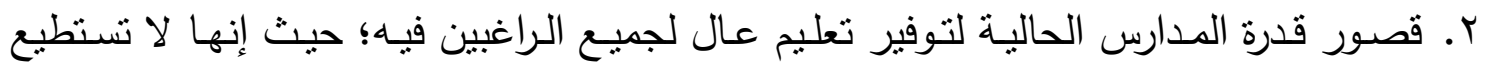

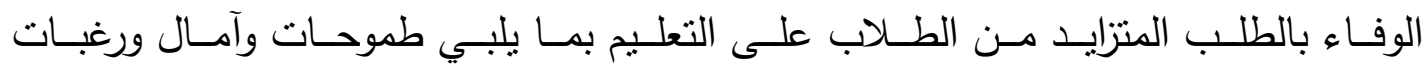

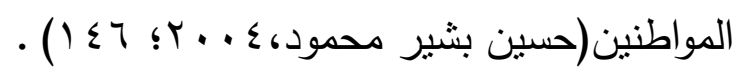

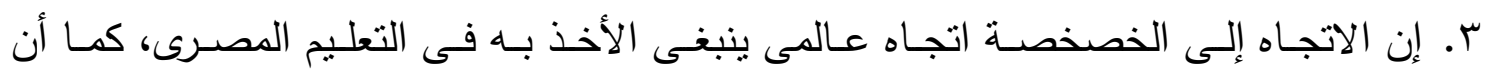

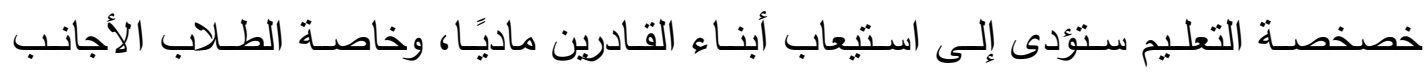

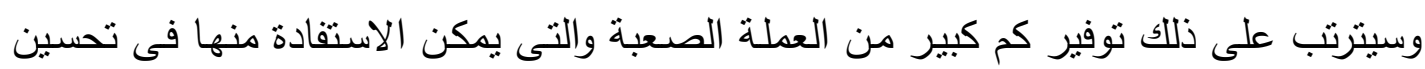

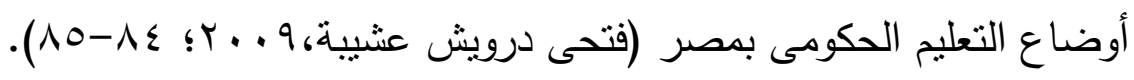

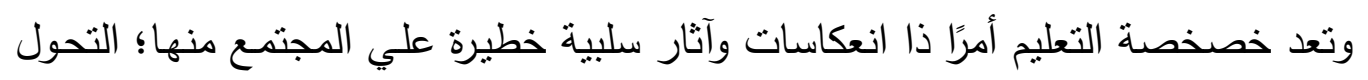

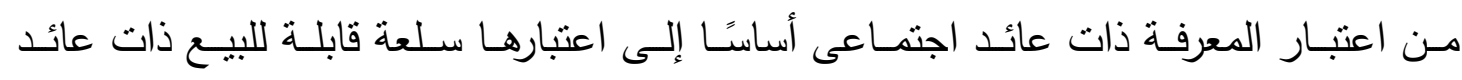

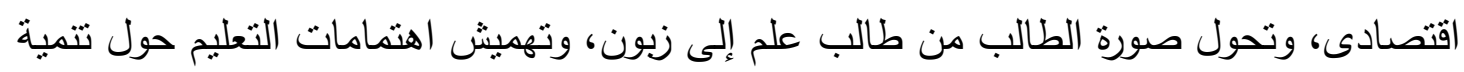

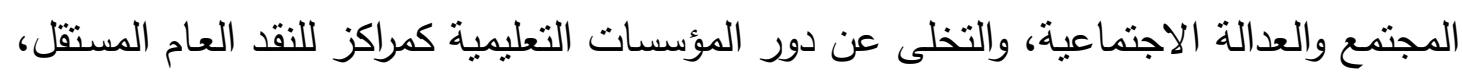

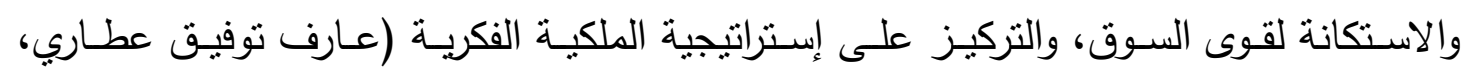

$$
\text { .( IV. - ITV V Y.. V }
$$

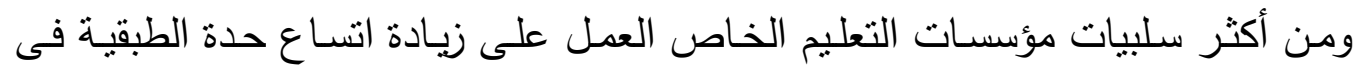

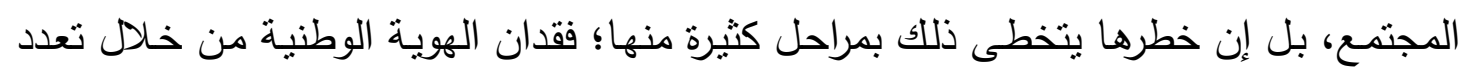

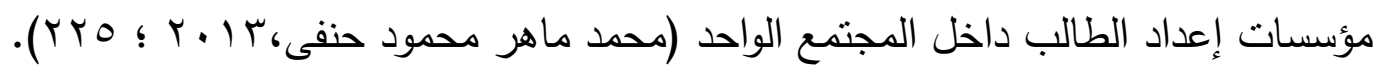

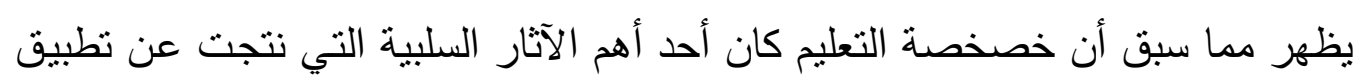

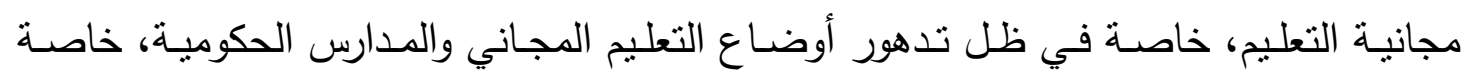

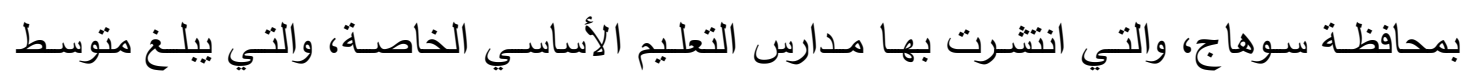

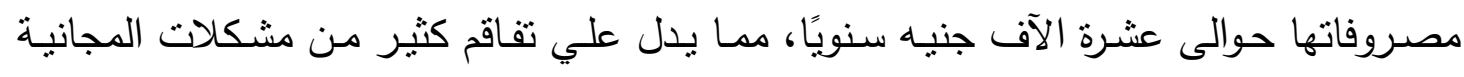

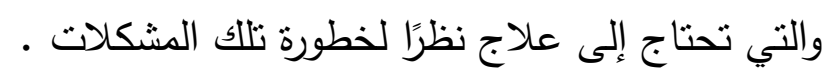

\section{مقترحسات لمواجهـة الآثـار السـلبية لتطبيـق مجانيـة التعلـيم الأساسـي بمحافظـة}

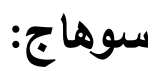
ا ـ زيادة الدعم الحكومي للتعليم المجاني بزيادة حصـة التعليم الأساسي من الميزانية العامـة للاولة

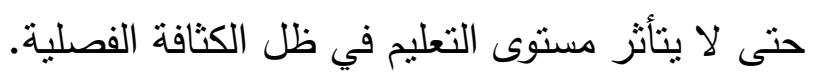

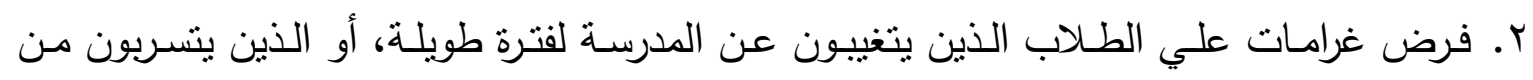

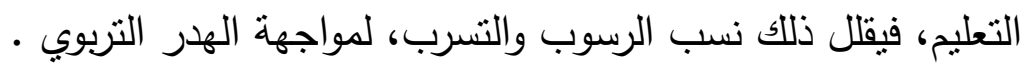




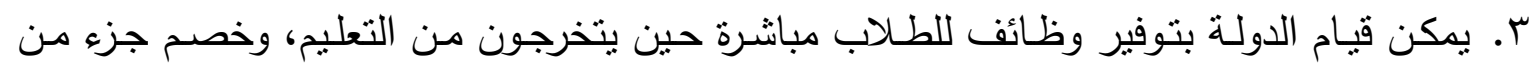

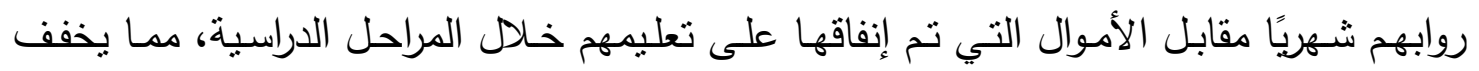

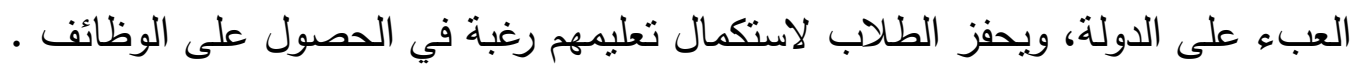

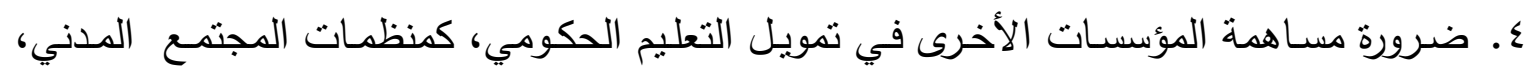

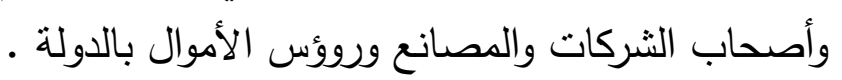

ه. العمل على التعاون مع هيئة الأبنية التعليمية لإنشاء مدارس للطلاب، لإلت لتخفيف الكثافة الفصلية .

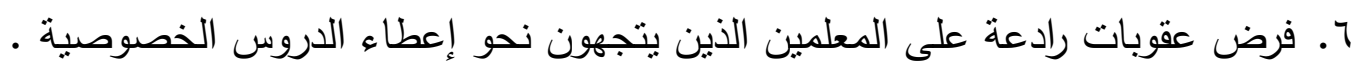
V. إلزام جميع مدارس التعليم الأساسي بسوهاج بتطبيق معايير الجودة وذلك بأقل الإمكانات المتاحة الثين

1. البحث عن مصادر تمويل ذاتية وتطبيق فكرة أو مشروع المدارس المنتجة لتوفير عائدمادي يسهم

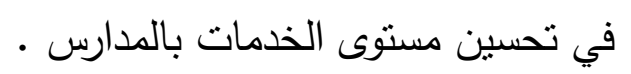

9. المتابعة الدورية لأداء المعلمين وتزويدهم بدورات ندريبية لتحسين أدائهم ونشر نقافة الجودة لايهمه.

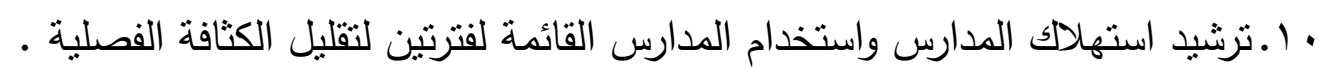

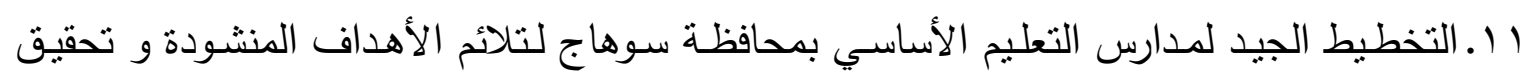

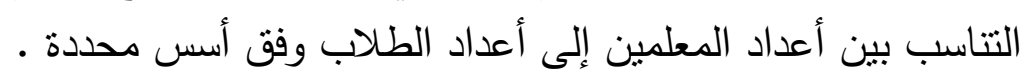

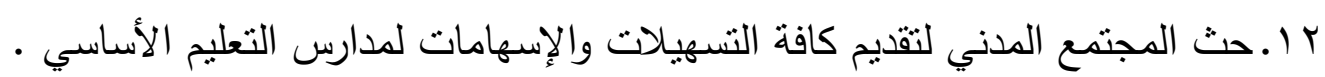

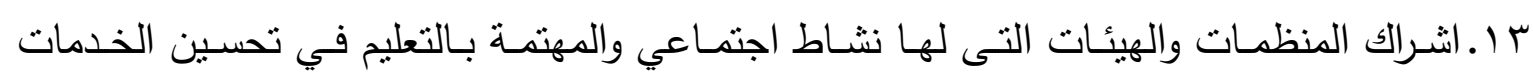
التعليمية في مدارس التعليم الأساسي .

\section{مراجع يمكن الإطلاع عليها:}

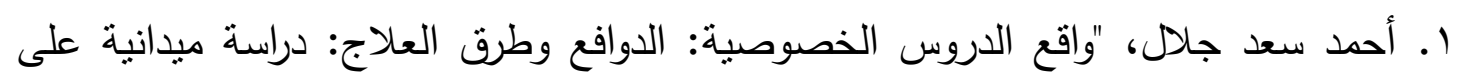

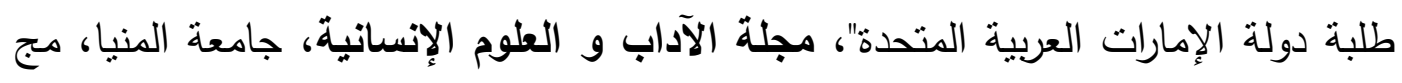

$$
\text { (r) }
$$

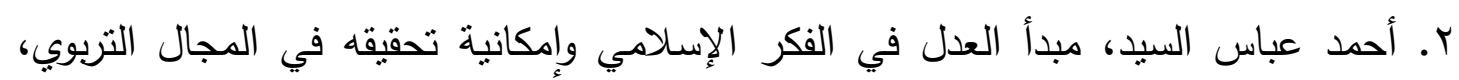

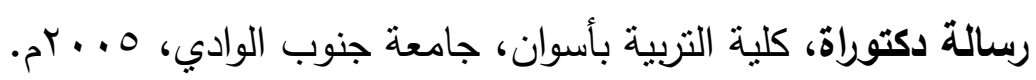

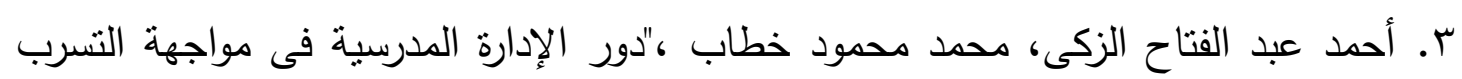

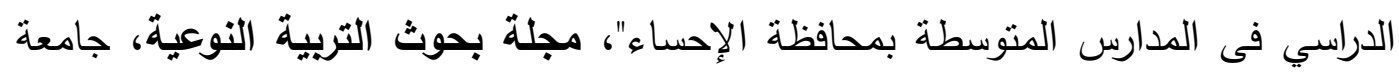

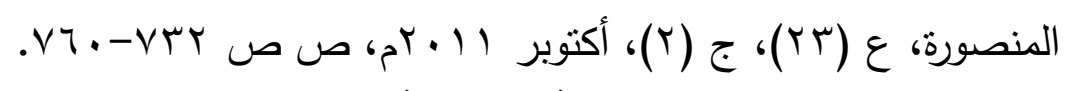

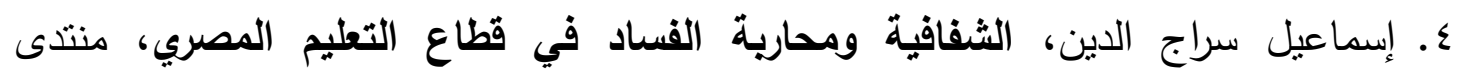

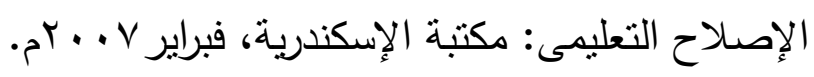


ه. حسن سلامة الفقي، "تكافؤ الفرص التعليمية ومجتمع الجدارة"، مجلة العلوم الاجتماعية،

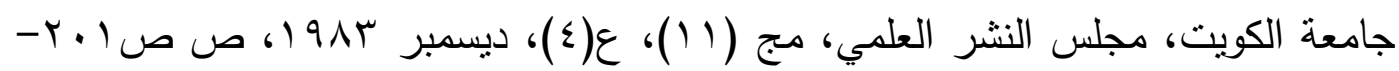
- TrT

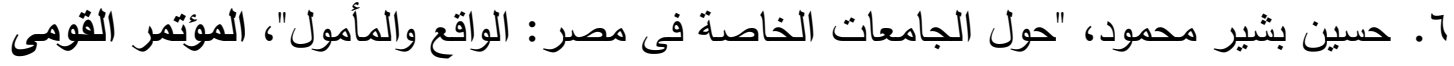

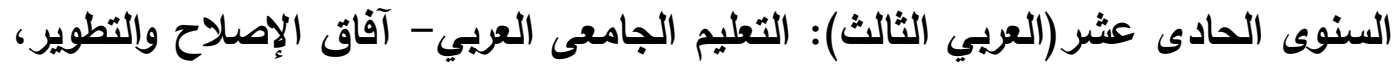

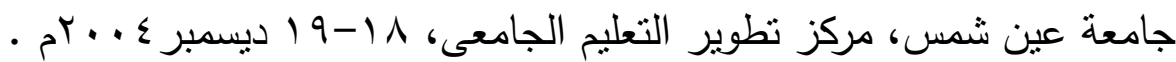
V. شبل بدران، "ديمقراطية التعليم والثقافة المجانية وتكافؤ الفرص أهم معالم ديمقراطية التعليم

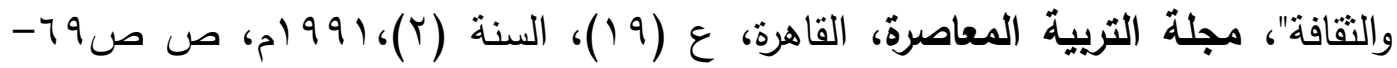
. I TE ^. عارف توفيق عطاري، صالحة عبداله عبسان، وجيهة ثابت العاني ، إتجاهات حديثة فى

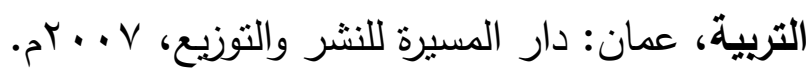
9. عبد الحميد عبد الفتاح شعلان، السياسة التعليمية بين الواقع والمأمول، القاهرة:

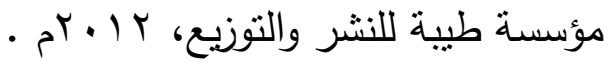

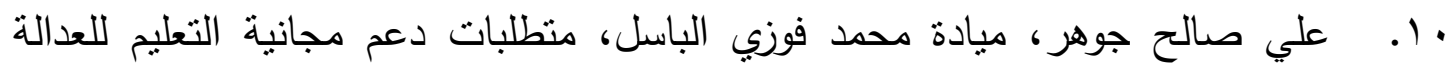

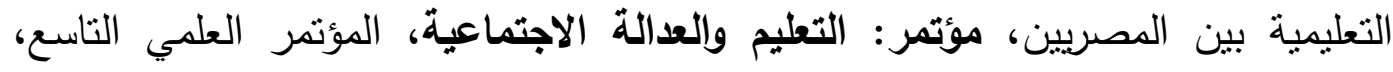

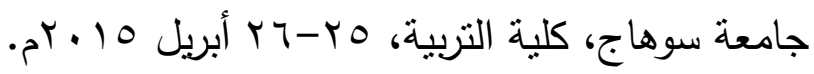
11 . فتحى درويش عشيية، تطوير التعليم الجامعى فى ضوء التحديات المعاصرة، القاهرة:

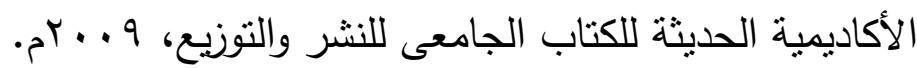

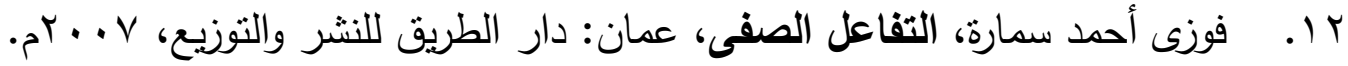

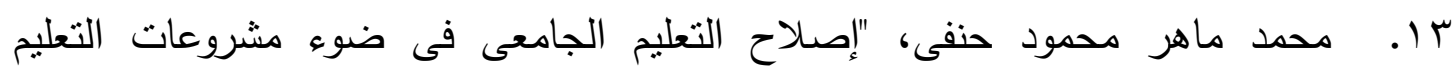

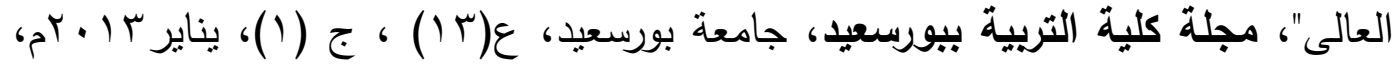

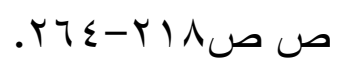

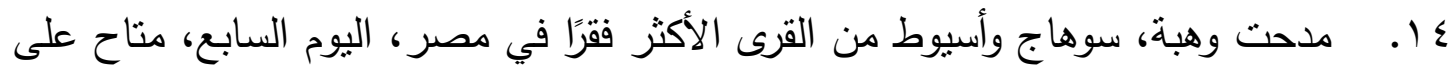

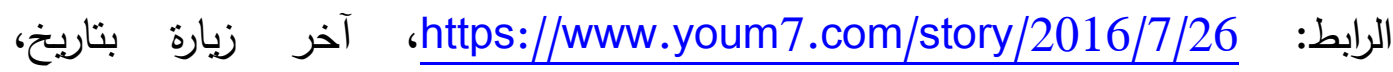
$\cdot \rho^{r \cdot 19 / r / \varepsilon}$ 10. وفية محمد عبد الجليل، تربية الأطفال فى المناطق العشوائية: دراسات نظرية

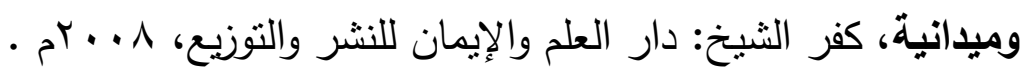


